\title{
Stoichiometries of remineralisation and denitrification in global biogeochemical ocean models
}

\author{
A. Paulmier ${ }^{1, *}$, I. Kriest ${ }^{1}$, and A. Oschlies ${ }^{1}$ \\ ${ }^{1}$ Leibniz-Institute of Marine Sciences IFM-GEOMAR, Düsternbrooker Weg 20, 24105 Kiel, Germany \\ * currently at: Max Planck Institute for Marine Microbiology, Celsiusstr. 1, 28359 Bremen, Germany
}

Received: 28 January 2009 - Published in Biogeosciences Discuss.: 26 February 2009

Revised: 6 May 2009 - Accepted: 18 May 2009 - Published: 28 May 2009

\begin{abstract}
Since the seminal paper of Redfield (1934), constant stoichiometric elemental ratios linking biotic carbon and nutrient fluxes are often assumed in marine biogeochemistry, and especially in coupled biogeochemical circulation models, to couple the global oxygen, carbon and nutrient cycles. However, when looking in more detail, some deviations from the classical Redfield stoichiometry have been reported, in particular with respect to remineralization of organic matter changing with depth or with ambient oxygen levels. We here compare the assumptions about the stoichiometry of organic matter and its remineralization that are used explicitly and implicitly in common biogeochemical ocean models. We find that the implicit assumptions made about the hydrogen content of organic matter can lead to inconsistencies in the modeled remineralization and denitrification stoichiometries. It is suggested that future marine biogeochemical models explicitly state the chemical composition assumed for the organic matter, including its oxygen and hydrogen content.
\end{abstract}

\section{Introduction}

The relative success of coupled biogeochemical (BGC) circulation models in simulating the oceanic component of the global carbon cycle relies to a large extent on the assumption of constant stoichiometric ratios linking biotic carbon and nutrient fluxes (Redfield, 1934). On average, the "Redfield picture" seems to work relatively well for net biotically induced fluxes in the upper ocean (e.g. Maier-Reimer, 1993; Aumont and Bopp, 2006; Moore and Doney, 2007). Some spatial/temporal deviations from the classical constant Redfield stoichiometry (Sambrotto et al., 1993; Schneider et al., 2003; Koeve, 2004), in particular at greater depths

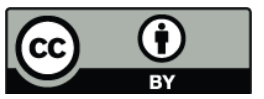

Correspondence to: A. Paulmier (apaulmier@ifm-geomar.de) attributed to (sedimentary) denitrification for the N/P ratio (Anderson and Sarmiento, 1994) and in the oxygen minimum zones (Van Mooy et al., 2002), become apparent with respect to changes in the carbon to nutrient ratios of organic matter and the oxygen demand associated with its remineralisation. As a result of these uncertainties, different biogeochemical models focusing on different time and depth scales sometimes use different factors to convert from nutrients to carbon. Most first-generation biogeochemical models avoid the explicit consideration of oxygen-sensitive non-Redfield processes like denitrification or anammox (e.g. Maier-Reimer, 1993). Although there is no agreement concerning the threshold in oxygen that defines the extent of the denitrification and anammox area (e.g. Paulmier and RuizPino, 2008), these processes are limited to very low oxygen concentrations and lead to a loss of fixed nitrogen. There is evidence that the intensity of this nitrogen loss has varied in concert with the extension of suboxic waters in the past (Altabet et al., 1995; Ganeshram et al., 2002), and there is concern that ongoing global change may lead to both the recent decline of oxygen levels in the tropical oceans (Stramma et al., 2008) and to a substantial increase in denitrification during this century (Oschlies et al., 2008).

So far, relatively little emphasis has been put on suboxic areas simulated by biogeochemical circulations models. A cursory look at recently published results of various biogeochemical climate models reveals that all models seem to have considerable difficulties getting the extent and intensity of the main oceanic oxygen minimum zones (OMZs) right. Typically, simulated OMZs have too large extensions, both in the horizontal and in the vertical direction. Subsurface oxygen levels are too low along the equatorial Pacific and in the Bay of Bengal, whereas global models generally fail to reach observed suboxic conditions in the Arabian Sea (e.g. Meissner et al., 2005; Moore and Doney, 2007; Schmittner et al., 2008).

Published by Copernicus Publications on behalf of the European Geosciences Union. 
The general tendency of too large extensions of the suboxic or even anoxic regions is expected to lead to overestimates in denitrification rates and the associated loss of fixed nitrogen. Potential explanations for this apparently systematic deficiency across various different models include possible errors in the physical transport terms (too low ventilation, too low mixing), in the euphotic zone processes (too high export production), and in the aphotic processes (too high remineralisation/respiration rates). This note aims at a better understanding of the relevant stoichiometric assumptions used by the different biogeochemical models to simulate oxic and suboxic remineralisation processes. We will comment what the different biogeochemical models have in common, how they differ and how this could impact on the simulated distributions of oxygen and other biogeochemical tracers. To this extent we focus on four global BGC models:

- the HAMOCC 5.1 model (HAMburg Ocean Carbon Cycle; Six and Maier-Reimer, 1996; Maier-Reimer et al., 2005);

- the PISCES model (Pelagic Interaction Scheme for Carbon and Ecosystem Studies; Aumont, 1998; Aumont and Bopp, 2006);

- the BEC model (Biogeochemical Elemental Cycling Moore et al. (2002) in the three-dimensional constantstoichiometry implementation of Moore and Doney (2007)

- the SCHMITTNER model, Schmittner et al., 2008).

All these global biogeochemical models are extensions of NPZD (nutrient, phytoplankton, zooplankton, detritus) type ecosystem models including aerobic remineralisation, denitrification and nitrogen fixation. All four use fixed $\mathrm{O}_{2} / \mathrm{C} / \mathrm{N} / \mathrm{P}$ ratios in organic matter and/or its production and decomposition, and simulate cycling of carbon, oxygen, nitrogen and phosphorus in the water column, and for HAMOCC also in the sediment. HAMOCC and PISCES have explicit $\mathrm{O}_{2} / \mathrm{C} / \mathrm{N} / \mathrm{P}$ ratios very similar to each other, whereas these ratios are quite different for BEC and especially for SCHMITTNER (e.g. $\mathrm{O}_{2} / \mathrm{C}$ of: $\approx 1.4$ for HAMOCC and PISCES; $\approx 1.5$ for BEC; $\approx 1.9$ for SCHMITTNER). In addition, PISCES and BEC explicitly include two phytoplankton and two zooplankton size-classes, and four phytoplankton functional groups (diazotrophs, diatoms, pico/nano-plankton, and coccolithophores), respectively. SCHMITTNER uses an expanded NPZD ecosystem model with a parameterization of fast nutrient recycling due to microbial activity that emerged from a North Atlantic data assimilation study (Schartau and Oschlies, 2003).

Referring to these models we will in this note examine the specific assumptions about the $\mathrm{C} / \mathrm{P}, \mathrm{N} / \mathrm{P},-\mathrm{O}_{2} / \mathrm{P}$ and $-\mathrm{NO}_{3} / \mathrm{P}$ ratios used in the respective models, and how these differ among the different models. We will also diagnose and discuss the implicit choices these models make about the $\mathrm{C} / \mathrm{H}$ and $\mathrm{H} / \mathrm{O}$ ratios of particulate organic matter, as these ratios impact on the oxidant requirements during aerobic and anaerobic remineralization.

In this paper, we will not consider dissolved organic matter because this is not included in all models. In contrast to particulate organic matter, it will move with the water, i.e. away from the surface its input to any domain will always be accompanied by the corresponding nutrient and oxygen values. Here, we therefore employ the term "organic matter" as synonym for particulate organic matter. As we will see below, large variations in the oxidant requirements during remineralization can occur even for the assumed narrow $\mathrm{C}: \mathrm{N}: \mathrm{P}$ ranges of particulate organic matter, mainly as a result of different implicit assumptions on the hydrogen and oxygen content of the organic matter.

The paper is organized as follows: the subsequent section gives a brief historical overview over stoichiometric relationships used to represent organic matter in the ocean. Section 3 then focuses on the stoichiometric description of aerobic and anaerobic remineralisation processes. The explicit and implicit assumptions made by the different biogeochemical models are discussed in Sect. 4, before Sect. 5 concludes the short note with a discussion of the possible impacts of using different stoichiometric assumptions in different biogeochemical models.

\section{Organic matter stoichiometries}

\subsection{Classical notation}

The classical expression for the composition of organic matter (OM), proposed by Richards (1965), assigns specific components to the different chemical elements, e.g. carbohydrates to the C-component, ammonia $\left(\mathrm{NH}_{3}\right)$ to the $\mathrm{N}$ component, and $\mathrm{H}_{3} \mathrm{PO}_{4}$ to the $\mathrm{P}$-component:

$\left(\mathrm{CH}_{2} \mathrm{O}\right)_{x}\left(\mathrm{NH}_{3}\right)_{y} \mathrm{H}_{3} \mathrm{PO}_{4}$,

denoting the ratio of nitrogen to phosphorus in organic matter as $y$, and the ratio of carbon to phosphorus in organic matter as $x$.

Phosphorus is contained in cells among others as nucleic acids, phospholipids, phosphoproteins, or inorganic phosphate. Making no assumption about the species of phosphorus assimilated or released (see also Brewer and Goldman, 1976) traditional notations assumed it in the form of $\mathrm{H}_{3} \mathrm{PO}_{4}$ in water as well as in $\mathrm{OM}$, without any change during remineralisation (e.g. Richards, 1965). Therefore, this form will be considered here, as phosphate is the classical form of phosphorus used in BGC models.

Likewise for the nitrogen, OM nitrogen has been described in amino form $\left(\mathrm{NH}_{3}\right)$. Following Richards (1965), we assume that the first step of organic decomposition is the hydrolytic release of $\mathrm{NH}_{4}^{+}$(and corresponding $\mathrm{OH}^{-}$) ions. The 
ammonia released is then oxidized during the (autotrophic) nitrification to nitrite and nitrate.

Concerning the $\mathrm{C}, \mathrm{H}$ and the oxygen demand for remineralisation, the classical works by Richards (1965) and Redfield et al. (1963) used $\mathrm{CH}_{2} \mathrm{O}$ for the composition of organic matter, i.e., they referred to organic matter that consisted mainly of carbohydrates (monosaccharides). However, in reality carbohydrates (not necessarily monosaccharides) only constitute about $5-41 \%$ of the biomass (Anderson, 1995). The remainder consists of proteins $(47-65 \%)$, lipids (5-31\%), and a small amount of nucleic acids (1-7\%; from Anderson, 1995; Hedges et al., 2002). Especially lipids, but also proteins can drive the H/O ratio of organic matter towards higher values (e.g. Anderson, 1995; Fraga et al., 1998).

The above considerations lead to the modified notation of organic matter:

$\mathrm{C}_{x}\left(\mathrm{H}_{2} \mathrm{O}\right)_{w}\left(\mathrm{NH}_{3}\right)_{y} \mathrm{H}_{z} \mathrm{H}_{3} \mathrm{PO}_{4}$

where $x$ and $y$ denote the same as for Eq. (1), and w denotes the amount of water in organic matter (more precisely: the $\mathrm{H}$ and $\mathrm{O}$ atoms that can be combined in a ratio of 2 to form water), while $\mathrm{z}$ denotes "excess" hydrogen (e.g., from lipids, polysaccharides or proteins). The oxidation of this "excess" hydrogen (implying more reduced carbonated and/or nitrogeneous compounds for OM, e.g., Laws, 1991), increases the oxygen demand that is required to oxidize organic matter. While the "classical" value for oxygen demand is 138 moles oxygen per organic matter with one mole of phosphorus, calculations based on the different constituents of phytoplankton cells suggested an oxygen demand of 149150 moles (Anderson, 1995; Fraga et al., 1998) and of up to 154 moles using nuclear magnetic resonance determination (Hedges et al., 2002). Calculations from inorganic dissolved seawater properties $\left(\mathrm{HNO}_{3}, \mathrm{H}_{3} \mathrm{PO}_{4}\right.$, Total $\left.\mathrm{CO}_{2}, \mathrm{O}_{2}\right)$ resulted in oxygen demands of about $165-178$ moles per organic matter with one mole of phosphorus (Takahashi et al., 1985; Anderson and Sarmiento, 1994). Boulahdid and Minster (1989) found a variation of the oxygen demand between 108-200 moles per organic matter with one mole of phosphorus for different isopycnals. Note that most of these calculations from dissolved inorganic constituents implicitly include nitrification (i.e., they include the complete oxidation of organic nitrogen to nitrate), and that accounting for this process has an effect on the estimated oxygen demand (see below). Note also that, in contrast to the "excess" hydrogen, the high level of organic oxygen proposed by Redfield et al. (1963) would lead to an underestimate of the amount of $\mathrm{O}_{2}$ required for complete respiration of plankton biomass (e.g. Hedges et al., 2002). BGC models (e.g. HAMOCC, PISCES) often use an oxygen demand similar to that proposed in Takahashi et al. (1985). However, the "excess" hydrogen implicitly associated with the elemental composition and oxygen or nitrate demand reveals considerable deviations among different estimates of $z$, ranging from $48-56$ moles (e.g. Anderson, 1995; Hedges et al., 2002, respectively) to 148 moles (e.g.
Takahashi et al., 1985), and even including negative values $(\approx-80)$ when considering amino-acids from algal proteins (e.g. Laws, 1991). Here, we will consider the Redfield formulation, as the historical reference, and the formulation of Anderson (1995), as one of the common formulation used since the last decade.

\subsection{General notation}

Using notation 2 for the composition of organic matter, remineralisation under oxic conditions can be expressed as

$$
\begin{array}{r}
\mathrm{C}_{x}\left(\mathrm{H}_{2} \mathrm{O}\right)_{w}\left(\mathrm{NH}_{3}\right)_{y} \mathrm{H}_{z} \mathrm{H}_{3} \mathrm{PO}_{4}+\left(x+\frac{1}{4} z\right) \mathrm{O}_{2} \longrightarrow \\
x \mathrm{CO}_{2}+y \mathrm{NH}_{3}+\mathrm{H}_{3} \mathrm{PO}_{4}+\left(w+\frac{1}{2} z\right) \mathrm{H}_{2} \mathrm{O}
\end{array}
$$

This equation immediately shows that the amount of oxygen required to remineralise organic matter with one mole of phosphorus depends on the excess hydrogen, i.e., on the proportion of lipids, proteins, polysaccharides, etc. With increasing $z$, the oxygen demand for remineralisation increases. For the special case of $w=x$ and $z=0$, we recover Eq. (1).

An alternative notation of the composition of organic matter is based on the bulk chemical composition of OM. Allowing an easy access to estimates of bulk OM composition, this notation has been used by Anderson (1995) and Fraga et al. (1998) and also by other approaches, e.g. by Takahashi et al. (1985). In this notation, OM is described by

$\mathrm{C}_{a} \mathrm{H}_{b} \mathrm{O}_{c} \mathrm{~N}_{d} \mathrm{P}$

The indices relate to the those of relation 2 via:

$$
\begin{aligned}
w & =c-4 \\
x & =a \\
y & =d \\
z & =b-2 c-3 d+5
\end{aligned}
$$

where $a, b, c$ and $d$ are the (measureable) stoichiometric ratios of particulate organic matter (in relation to one mole P), and may potentially vary between $a \approx 53-108$ and $d \approx 16-18$ (Copin-Montegut and Copin-Montegut, 1983; Laws, 1991; Anderson, 1995; Hedges et al., 2002), including the classical Redfield values of 106 and 16 for carbon and nitrogen, respectively (see also Table 1 ). Note that the lowest $a \approx 53$ correspond to algal proteins analysis (Laws, 1991). The latter notation 4 provides immediate insight into the elemental ratios and is often used by modelers, although most models explicitly prescribe only $\mathrm{C}_{a} \mathrm{~N}_{d} \mathrm{P}$. As we will see below, the models do, however, make implicit assumptions about $\mathrm{H}_{b} \mathrm{O}_{c}$ via the parameterisation of the $\mathrm{OM}$ remineralisation processes. 
Table 1. Stoichiometric ratios of organic matter and its remineralisation as well as its effect on Total Alkalinity (TA). $\mathrm{C}_{\mathrm{org}}, \mathrm{H}_{\mathrm{org}}, \mathrm{O}_{\mathrm{org}}$, $\mathrm{N}_{\text {org }}$ and $\mathrm{P}_{\text {org }}$ denote $\mathrm{C}, \mathrm{H}, \mathrm{O}, \mathrm{N}$ and $\mathrm{P}$ contained in organic matter, respectively. ${ }^{\text {a }}$ Stoichiometric ratios of organic matter composition from Redfield et al., 1963; Copin-Montegut and Copin-Montegut, 1983; Laws, 1991 (lowest $a, b$ and $c$, considering algal proteins), Anderson, 1995; Fraga et al., 1998 and Hedges et al., 2002. ${ }^{\mathrm{b}} \mathrm{NH}_{3} / \mathrm{P}_{\text {org }}=d$ for all specific processes. To minimize the number of parameters, the values of the processes have been expressed in terms of $R_{0}$ whenever possible.

\begin{tabular}{|c|c|c|c|}
\hline Equation & Ratio & Name & Value \\
\hline \multicolumn{4}{|c|}{ Organic matter composition ${ }^{\mathrm{a}}$} \\
\hline 4 & $\mathrm{C}_{\text {org }} / \mathrm{P}_{\text {org }}$ & $a$ & $\approx 53-108$ \\
\hline 4 & $\mathrm{H}_{\text {org }} / \mathrm{P}_{\text {org }}$ & $b$ & $\approx 7-263$ \\
\hline 4 & $\mathrm{O}_{\text {org }} / \mathrm{P}_{\text {org }}$ & $c$ & $\approx 23-110$ \\
\hline 4 & $\mathrm{~N}_{\text {org }} / \mathrm{P}_{\text {org }}$ & $d$ & $\approx 16-18$ \\
\hline \multicolumn{4}{|c|}{ Specific processes $^{b}$} \\
\hline \multicolumn{4}{|c|}{ Oxic: Remineralisation } \\
\hline 6 & $-\mathrm{O}_{2} / \mathrm{P}_{\text {org }}$ & $R_{0}$ & $a+1 / 4 b-1 / 2 c-3 / 4 d+5 / 4$ \\
\hline 6 & $\mathrm{TA} / \mathrm{P}_{\text {org }}$ & & $d-1$ \\
\hline \multicolumn{4}{|c|}{ Suboxic: Denitrification I } \\
\hline 13 & $-\mathrm{HNO}_{3} / \mathrm{P}_{\text {org }}$ & & $2 R_{0}$ \\
\hline 13 & $\mathrm{HNO}_{2} / \mathrm{P}_{\text {org }}$ & & $2 R_{0}$ \\
\hline 13 & $\mathrm{TA} / \mathrm{P}_{\text {org }}$ & & $d-1$ \\
\hline \multicolumn{4}{|c|}{ Suboxic: Denitrification II } \\
\hline 14 & $-\mathrm{HNO}_{2} / \mathrm{P}_{\text {org }}$ & & $4 / 3 R_{0}$ \\
\hline 14 & $\mathrm{~N}_{2} / \mathrm{P}_{\text {org }}$ & & $2 / 3 R_{0}$ \\
\hline 14 & $\mathrm{TA} / \mathrm{P}_{\text {org }}$ & & $4 / 3 R_{0}+d-1$ \\
\hline \multicolumn{4}{|c|}{ Suboxic: Denitrification I+II } \\
\hline 15 & $-\mathrm{HNO}_{2} / \mathrm{P}_{\text {org }}$ & & $4 / 5 R_{0}$ \\
\hline 15 & $\mathrm{~N}_{2} / \mathrm{P}_{\text {org }}$ & & $2 / 5 R_{0}$ \\
\hline 15 & $\mathrm{TA} / \mathrm{P}_{\text {org }}$ & & $4 / 5 R_{0}+d-1$ \\
\hline \multicolumn{4}{|c|}{ Bulk processes } \\
\hline \multicolumn{4}{|c|}{ Oxic: Remineralisation plus nitrification } \\
\hline 10 & $-\mathrm{O}_{2} / \mathrm{P}_{\text {org }}$ & & $R_{0}+2 d$ \\
\hline 10 & $\mathrm{HNO}_{3} / \mathrm{P}_{\text {org }}$ & & $d$ \\
\hline 10 & $\mathrm{TA} / \mathrm{P}_{\text {org }}$ & & $-d-1$ \\
\hline \multicolumn{4}{|c|}{ Suboxic: Denitrification I+II+oxidation of $\mathrm{NH}_{3}$ by $\mathrm{HNO}_{3}$} \\
\hline 18 & $-\mathrm{HNO}_{3} / \mathrm{P}_{\mathrm{org}}$ & & $4 / 5 R_{0}+3 / 5 d$ \\
\hline 18 & $\mathrm{~N}_{2} / \mathrm{P}_{\text {org }}$ & & $2 / 5 R_{0}+4 / 5 d$ \\
\hline 18 & $\mathrm{TA} / \mathrm{P}_{\text {org }}$ & & $4 / 5 R_{0}+3 / 5 d-1$ \\
\hline
\end{tabular}

\section{Stoichiometry of remineralisation processes}

This section describes the different heterotrophic and autotrophic remineralisation processes that take place in the water column. In our approach, as well as in the models discussed later on, any bacteria involved in the aerobic and the anaerobic processes are assumed to act simply as catalysts. Making no specific assumptions about their physiology and/or abundance, we simply assume zero net growth of the bacteria, and that all processes happen at the same rate (in the following denoted by $v_{1}, v_{2}, \ldots$ ).

Accounting for the "electroneutrality" of the bacteria requires that they release or take up $\mathrm{OH}^{-}$(alternatively, $\mathrm{H}^{+}$), and thus affect the alkalinity of the surrounding seawater. The exact formulation how the bacteria regulate their internal ion concentrations is not the scope of this paper - for a comprehensive discussion, see Wolf-Gladrow et al. (2007). (For the effects of phytoplankton growth on alkalinity see also Brewer and Goldman, 1976; Goldman and Brewer, 1980 or Fraga and Alvarez-Salgado, 2005.) Instead of accounting for $\mathrm{OH}^{-}$ions, an alternative approach is to account for the fixed nitrogen ions (nitrate, nitrite, ammonia) directly, and to evaluate the corresponding changes in alkalinity from Eq. (32) of Wolf-Gladrow et al. (2007).

In our paper we assume that the bacteria release the uncharged, non-dissociated forms of all nutrients. For phosphate, nitrite and ammonia, this directly feeds into the $\mathrm{TPO}_{4}$, $\mathrm{THNO}_{2}$ and $\mathrm{TNH}_{3}$ terms of Eq. (32) of Wolf-Gladrow et al. (2007). Assuming immediate dissociation of $\mathrm{HNO}_{3}$ to $\mathrm{NO}_{3}^{-}+\mathrm{H}^{+}$after bacterial release, the nitrate then also adds 
to the alkalinity. The advantage of this expression is that the approach is explicitly conservative (to e.g. temperature and pressure changes, see Wolf-Gladrow et al., 2007), and that the alkalinity changes associated with release or consumption of nutrients are easily inferred from the equations.

\subsection{Aerobic processes}

Aerobic remineralisation will take place under oxic conditions. In biogeochemical models, the oxygen threshold for the transition from aerobic to anaerobic remineralisation processes is generally assumed to be near $4 \mu \mathrm{MO}_{2}$.

\subsubsection{Heterotrophy: remineralisation of OM}

Aerobic remineralisation of $\mathrm{OM}$ is a heterotrophic process that produces ammonia and increases the alkalinity by $(d-1)$ moles for each mole phosphorus remineralised. The rate of this process is denoted as $v_{1}$ :

$$
\begin{array}{r}
\mathrm{C}_{a} \mathrm{H}_{b} \mathrm{O}_{c} \mathrm{~N}_{d} \mathrm{P}+\left(a+\frac{1}{4} b-\frac{1}{2} c-\frac{3}{4} d+\frac{5}{4}\right) \mathrm{O}_{2} \stackrel{v_{1}}{\longrightarrow} \\
a \mathrm{CO}_{2}+d \mathrm{NH}_{3}+\mathrm{H}_{3} \mathrm{PO}_{4}+\left(\frac{1}{2} b-\frac{3}{2} d-\frac{3}{2}\right) \mathrm{H}_{2} \mathrm{O}
\end{array}
$$

The amount of oxygen that is required to remineralise organic matter with one mole of phosphorus during aerobic remineralisation can be expressed here by $R_{0}=a+1 / 4 b-1 / 2 c-3 / 4 d+5 / 4$ (expression used in Table 1).

\subsubsection{Autotrophy: nitrification of ammonia to nitrate}

This is a two step process: first oxidation of ammonia to nitrite, then oxidation of nitrite to nitrate. These proceed at rates $v_{2}$ and $v_{3}$ for the oxidation of ammonia to nitrite, and nitrite to nitrate, respectively. Thus, the $d$ moles of ammonia obtained by heterotrophic remineralisation of OM (Eq. 6) are nitrified as follows:

$$
\begin{aligned}
& d \mathrm{NH}_{3}+\frac{3}{2} d \mathrm{O}_{2} \stackrel{v_{2}}{\longrightarrow} d \mathrm{HNO}_{2}+d \mathrm{H}_{2} \mathrm{O} \\
& d \mathrm{HNO}_{2}+\frac{1}{2} d \mathrm{O}_{2} \stackrel{v_{3}}{\longrightarrow} d \mathrm{HNO}_{3}
\end{aligned}
$$

Note that only the oxydation of ammonia to nitrite has an effect on alkalinity (decrease by two moles for one mole nitrogen oxidised). Summing up the two equations yields

$$
d \mathrm{NH}_{3}+2 d \mathrm{O}_{2} \longrightarrow d \mathrm{HNO}_{3}+d \mathrm{H}_{2} \mathrm{O}
$$

\subsubsection{Heterotrophy+Autotrophy: a shortcut for remineralisation of $\mathrm{OM}$}

Combining Eqs. (6) to (9) provides a shortcut for the immediate remineralisation of OM to nitrate, what we here denote as "Complete" aerobic Remineralisation (CR) for "heterotrophic aerobic remineralisation (Eq. 6) + nitrification (Eq. 9)":

$$
\begin{array}{r}
\mathrm{C}_{a} \mathrm{H}_{b} \mathrm{O}_{c} \mathrm{~N}_{d} \mathrm{P}+\left(a+\frac{1}{4} b-\frac{1}{2} c+\frac{5}{4} d+\frac{5}{4}\right) \mathrm{O}_{2} \longrightarrow(10) \\
a \mathrm{CO}_{2}+d \mathrm{HNO}_{3}+\mathrm{H}_{3} \mathrm{PO}_{4}+\left(\frac{1}{2} b-\frac{1}{2} d-\frac{3}{2}\right) \mathrm{H}_{2} \mathrm{O}
\end{array}
$$

This relationship is essentially the same as Eqs. $(2,3)$ of Anderson (1995). Associated with this process is a decrease of alkalinity by $(d+1)$ moles for each mole of organic phosphorus remineralised.

The following two paragraphs show two examples for the classical Redfield stoichiometry, as well as for a stoichiometry that accounts for more realistic OM composition:

Redfield stoichiometry: consider $a=106, d=16$. Assuming that the OM consists mainly of monosaccharides, $\mathrm{NH}_{3}$ and $\mathrm{H}_{3} \mathrm{PO}_{4}, b=2 a+3 d+3=263$ and $c=a+4=110$. Then the equation for $\mathrm{OM}$ remineralisation and instantaneous, complete nitrification is:

$$
\begin{gathered}
\mathrm{C}_{106} \mathrm{H}_{263} \mathrm{O}_{110} \mathrm{~N}_{16} \mathrm{P}+\left(\frac{4 \times 106+263-2 \times 110+5 \times 16+5}{4}\right) \mathrm{O}_{2} \longrightarrow \\
106 \mathrm{CO}_{2}+16 \mathrm{HNO}_{3}+\mathrm{H}_{3} \mathrm{PO}_{4}+\left(\frac{263-16-3}{2}\right) \mathrm{H}_{2} \mathrm{O}
\end{gathered}
$$

i.e., 138 moles of oxygen are required to remineralise organic matter with one mole of phosphorus to carbon dioxide, nitrate and 122 moles of water.

"Anderson" stoichiometry: Consider $a=106, b=175$, $c=42$ and $d=16$. This refers to the composition given by Anderson (1995), calculated from observed constituents of organic matter. Then the equation for OM remineralisation and instantaneous, complete nitrification is:

$$
\begin{gathered}
\mathrm{C}_{106} \mathrm{H}_{175} \mathrm{O}_{42} \mathrm{~N}_{16} \mathrm{P}+\left(\frac{4 \times 106+175-2 \times 42+5 \times 16+5}{4}\right) \mathrm{O}_{2} \longrightarrow( \\
106 \mathrm{CO}_{2}+16 \mathrm{HNO}_{3}+\mathrm{H}_{3} \mathrm{PO}_{4}+\left(\frac{175-16-3}{2}\right) \mathrm{H}_{2} \mathrm{O}
\end{gathered}
$$

i.e., 150 moles of oxygen are required to remineralise organic matter with one mole of phosphorus to carbon dioxide, nitrate and 78 moles of water.

Note, that the C/N/P stoichiometries of the two examples are identical as are the remineralisation products that contain C, N, and P. For biogeochemical models that focus on these chemical elements, results would therefore be undistinguishable. The examples differ, however, in the $\mathrm{O}$ and $\mathrm{H}$ content of organic matter and, as a result, in the oxygen demand during remineralisation. 


\subsection{Anaerobic processes}

The following processes (anaerobic remineralisation by denitrification; anammox) will take place under suboxic conditions, i.e. for ambient oxygen concentrations smaller than about $4 \mu \mathrm{MO}_{2}$.

\subsubsection{Heterotrophy: remineralisation of OM by denitri- fication}

Anaerobic remineralisation by denitrification of $\mathrm{OM}$ is a heterotrophic process that may involve several oxidation states of nitrogen. Here only nitrate, nitrite, and molecular nitrogen are considered. The oxidation of organic matter further produces ammonia (contained in OM). First, there is reduction of nitrate to nitrite proceeding at rate $v_{4}$, which increases the alkalinity by $(d-1)$ moles for each mole phosphorus remineralised:

$$
\begin{gathered}
\mathrm{C}_{a} \mathrm{H}_{b} \mathrm{O}_{c} \mathrm{~N}_{d} \mathrm{P}+\left(2 a+\frac{1}{2} b-c-\frac{3}{2} d+\frac{5}{2}\right) \mathrm{HNO}_{3} \stackrel{v_{4}}{\longrightarrow} \\
a \mathrm{CO}_{2}+d \mathrm{NH}_{3}+\mathrm{H}_{3} \mathrm{PO}_{4}+\left(\frac{1}{2} b-\frac{3}{2} d-\frac{3}{2}\right) \mathrm{H}_{2} \mathrm{O} \\
+\left(2 a+\frac{1}{2} b-c-\frac{3}{2} d+\frac{5}{2}\right) \mathrm{HNO}_{2}
\end{gathered}
$$

Then, nitrite is reduced to molecular nitrogen, with the rate constant $v_{5}$, and with an associated increase in alkalinity by $(4 / 3 a+1 / 3 b-2 / 3 c+2 / 3)$ moles:

$$
\begin{aligned}
\mathrm{C}_{a} \mathrm{H}_{b} \mathrm{O}_{c} \mathrm{~N}_{d} \mathrm{P}+\left(\frac{4}{3} a+\frac{1}{3} b-\frac{2}{3} c-d+\frac{5}{3}\right) \mathrm{HNO}_{2} \stackrel{v_{5}}{\longrightarrow} \\
\quad a \mathrm{CO}_{2}+d \mathrm{NH}_{3}+\mathrm{H}_{3} \mathrm{PO}_{4}+\left(\frac{2}{3} a+\frac{2}{3} b-\frac{1}{3} c-2 d-\frac{2}{3}\right) \mathrm{H}_{2} \mathrm{O} \\
+\left(\frac{2}{3} a+\frac{1}{6} b-\frac{1}{3} c-\frac{1}{2} d+\frac{5}{6}\right) \mathrm{N}_{2}
\end{aligned}
$$

Note that while Eq. (13) yields $(2 a+1 / 2 b-c-$ $3 / 2 d+5 / 2$ ) moles nitrite per organic matter with one mole of phosphorus remineralised, Eq. (14) requires $(4 / 3 a+1 / 3 b-2 / 3 c-d+5 / 3)$ moles nitrite to remineralise organic matter with one mole of phosphorus.

Summing up the two equations - more precisely: $2 / 5$ times Eq. (13) plus 3/5 times Eq. (14) - yields the "net" equation for denitrification, which is accompanied by an increase in alkalinity by $(4 / 5 a+01 / 5 b-2 / 5 c+2 / 5 d)$ moles:

$$
\begin{aligned}
\mathrm{C}_{a} \mathrm{H}_{b} \mathrm{O}_{c} \mathrm{~N}_{d} \mathrm{P}+\left(\frac{4}{5} a+\frac{1}{5} b-\frac{2}{5} c-\frac{3}{5} d+1\right) \mathrm{HNO}_{3} \rightarrow \\
a \mathrm{CO}_{2}+d \mathrm{NH}_{3}+\mathrm{H}_{3} \mathrm{PO}_{4}+\left(\frac{2}{5} a+\frac{3}{5} b-\frac{1}{5} c-\frac{9}{5} d-1\right) \mathrm{H}_{2} \mathrm{O} \\
+\left(\frac{2}{5} a+\frac{1}{10} b-\frac{1}{5} c-\frac{3}{10} d+\frac{1}{2}\right) \mathrm{N}_{2}
\end{aligned}
$$

or

$$
\mathrm{C}_{a} \mathrm{H}_{b} \mathrm{O}_{c} \mathrm{~N}_{d} \mathrm{P}+\left(\frac{4}{5} R_{0}\right) \mathrm{HNO}_{3} \longrightarrow
$$

$$
\begin{aligned}
& a \mathrm{CO}_{2}+d \mathrm{NH}_{3}+\mathrm{H}_{3} \mathrm{PO}_{4}+\left(\frac{2}{5} a+\frac{3}{5} b-\frac{1}{5} c-\frac{9}{5} d-1\right) \mathrm{H}_{2} \mathrm{O} \\
& +\left(\frac{2}{5} R_{0}\right) \mathrm{N}_{2}
\end{aligned}
$$

Richards (1965) and others have further assumed an immediate, complete oxidation of the ammonia released from organic matter during denitrification:

$d \mathrm{NH}_{3}+\frac{3}{5} d \mathrm{HNO}_{3} \longrightarrow \frac{4}{5} d \mathrm{~N}_{2}+\frac{9}{5} d \mathrm{H}_{2} \mathrm{O}$

Adding this process (equation implicitly used in the BGC models to convert the ammonium produced by anaerobic remineralisation (nitrate-respiration) into $\mathrm{N}_{2}$ ) to Eq. (15) yields the equation for Complete Denitrification (CD):

$$
\begin{aligned}
& \mathrm{C}_{a} \mathrm{H}_{b} \mathrm{O}_{c} \mathrm{~N}_{d} \mathrm{P}+\left(\frac{4}{5} a+\frac{1}{5} b-\frac{2}{5} c+1\right) \mathrm{HNO}_{3} \longrightarrow \\
& a \mathrm{CO}_{2}+\mathrm{H}_{3} \mathrm{PO}_{4}+\left(\frac{2}{5} a+\frac{3}{5} b-\frac{1}{5} c-1\right) \mathrm{H}_{2} \mathrm{O} \\
& +\left(\frac{2}{5} a+\frac{1}{10} b-\frac{1}{5} c+\frac{1}{2} d+\frac{1}{2}\right) \mathrm{N}_{2}
\end{aligned}
$$

CD results in an increase in alkalinity of $(4 / 5 a+1 / 5 b-2 / 5 c)$ moles.

\subsubsection{Autotrophy: anammox}

Ammonia and nitrite can be combined in an autotrophic process called "anaerobic ammonium oxidation" (anammox), with rate $v_{6}$ to molecular nitrogen and without any effect on alkalinity:

$d \mathrm{NH}_{3}+d \mathrm{HNO}_{2} \stackrel{v_{6}}{\longrightarrow} d \mathrm{~N}_{2}+2 d \mathrm{H}_{2} \mathrm{O}$

The ammonia required may have been produced either by anaerobic oxydation of OM (e.g. denitrification; DNRA or Dissimilatory Nitrate Reduction to Ammonium), or by aerobic remineralisation and subsequent transport into the lowoxygen "anammox region". In both cases, the ammonia will come from the decomposition of organic matter. Thus, as for nitrification, organic matter (particulate or dissolved) is required to feed this process. The nitrite required in the anammox reaction will either come from the first (aerobic) nitrification step (with subsequent transport to the "anammox" environment), or it may be produced as an intermediate product of denitrification (i.e., a heterotrophic process).

The extent to which anammox will change the ammonia, nitrite, nitrate and dinitrogen pools depends on the rates at which the different processes operate. So far, we have assumed that all processes take place at the same speed (in particular: $v_{1}=v_{2}=v_{3}$ for the aerobic, and $v_{4}=v_{5}$ for the anaerobic processes). For oxic conditions, anammox would compete with the first nitrifying step (Eq. 7) for ammonia, and with the second step of nitrification (Eq. 8) for nitrite. For 
suboxic conditions, anammox would compete with the second step of denitrification (Eq. 14) for nitrite. In addition, especially in the transition zone from oxic to anoxic conditions the rates of the processes may be affected by the oxygen sensitivity of the different organisms and processes involved. However, at this stage we can make the following thought experiment:

For oxic conditions, let us assume that anammox replaces the second step of nitrification (i.e., $v_{6} \gg v_{3}$ ). Then, adding Eqs. (7) and (19), dividing by two, and adding this to Eq. (6) yields:

$$
\begin{gathered}
\mathrm{C}_{a} \mathrm{H}_{b} \mathrm{O}_{c} \mathrm{~N}_{d} \mathrm{P}+\left(R_{0}+\frac{3}{4} d\right) \mathrm{O}_{2} \longrightarrow a \mathrm{CO}_{2} \\
+\frac{1}{2} d \mathrm{~N}_{2}+\mathrm{H}_{3} \mathrm{PO}_{4}+\left(\frac{1}{2} b-\frac{3}{2}\right) \mathrm{H}_{2} \mathrm{O}
\end{gathered}
$$

Thus, in contrast to complete remineralisation (i.e., aerobic remineralisation with the two steps of nitrification) which requires $R_{0}+2 d$ oxygen, this process requires less $\left(R_{0}+3 / 4 d\right)$ oxygen (e.g. $14 \%$ less for Redfield organic matter, cf. Sect. 3.1.3 and Table 1), but also removes fixed nitrogen and decreases alkalinity by 1 mole for each mole phosphorus of remineralised organic matter.

For suboxic conditons, we assume that anammox uses ammonia provided by both steps of denitrification (Eqs. 13 and 14); Adding anammox to Eqs. (13) and (14) separately, and then dividing the sum of these by two, yields the net gain of denitrification of organic matter associated with one mole phosphorous, plus anammox:

$$
\begin{gathered}
\mathrm{C}_{a} \mathrm{H}_{b} \mathrm{O}_{c} \mathrm{~N}_{d} \mathrm{P}+\left(R_{0}\right) \mathrm{HNO}_{3} \longrightarrow a \mathrm{CO}_{2}+\mathrm{H}_{3} \mathrm{PO}_{4} \\
+\left(\frac{1}{3} a+\frac{7}{12} b-\frac{1}{6} c+\frac{1}{4} d-\frac{13}{12}\right) \mathrm{H}_{2} \mathrm{O} \\
+\left(\frac{1}{3} R_{0}-d\right) \mathrm{HNO}_{2}+\left(\frac{1}{3} R_{0}+d\right) \mathrm{N}_{2}
\end{gathered}
$$

I.e. this combined process results in a higher $\mathrm{HNO}_{3}$ demand with less $\mathrm{N}_{2}$ produced (e.g. $+12 \%$ and $-7 \%$, respectively, for Redfield organic matter, cf. Sect. 3.1.3 and Table 1), but in a surplus of nitrite, as classically observed in denitrifying waters, and an increase of alkalinity by $\frac{2}{3} R_{0}+d-1$ moles for each mole phosphorus of remineralised organic matter. Note, that the presence of anammox could explain an $\mathrm{N}_{2}$ production exceeding the $\mathrm{HNO}_{3}$ deficit, as suggested by the observations of Devol et al. (2006), only if anammox is tightly coupled to nitrification (Eq. 20; cf. Lam et al., 2009).
However, as none of the models discussed below explicitly considers anammox, for now we will skip further consideration of the stoichiometric relation of anammox with the different steps of denitrification and nitrification.

\subsection{Implications}

\subsubsection{A stoichiometric oxygen switch}

Eqs. (6-18) present the process equations for aerobic and anaerobic remineralisation processes and their stoichiometries in terms of the composition of organic matter, as specified by the subscripts $a, b, c$, and $d$. The stoichiometric relationships between the different processes can be easily expressed by the amount of oxygen that is required to remineralise organic matter with one mole of phosphorus during incomplete aerobic remineralisation ( $R_{0}=a+1 / 4 b-1 / 2 c-3 / 4 d+5 / 4$ according to Eq. (6); used to express the stoichiometric ratios of the different processes in Table 1).

Making use of term $R_{0}$, we can now easily evaluate stoichiometric relationships between the different processes and their requirements in the oxic and suboxic zones: first, assume that all organic matter is remineralised to $\mathrm{CO}_{2}$, $\mathrm{H}_{3} \mathrm{PO}_{4}$, water and $\mathrm{NH}_{3}$ under suboxic and oxic conditions (cf. Eqs. 16 and 6). In this case the relation between nitrate demand (suboxic) to oxygen demand (oxic) is expressed by

$R_{\mathrm{HNO}_{3}: \mathrm{O}_{2}}^{*}=\frac{4 / 5 R_{0}}{R_{0}}=\frac{4}{5}$

i.e. 0.8 mole nitrate replace one mole oxygen. This is equivalent to the fact that 1 mole of $\mathrm{HNO}_{3}$ can accept $5 \mathrm{e}^{-}$ (if converted to $\mathrm{N}_{2}$ ) while 1 mole of $\mathrm{O}_{2}$ can accept only $4 \mathrm{e}^{-}$ (when reduced to water). As an example, Richards (1965) evaluates 106 moles oxygen demand for the aerobic remineralisation to $\mathrm{NH}_{3}$, and $84.4=4 / 5 \times 106$ moles nitrate demand for denitrification of organic matter to $\mathrm{NH}_{3}$.

However, ammonia does not accumulate significantly, but is readily converted to $\mathrm{HNO}_{3}$ in oxic waters through nitrification and similarly in suboxic waters, obviously since some reaction such as anammox convert it to $\mathrm{N}_{2}$ (e.g. Richards, 1965). This is why the notations e.g. by Richards (1965) and Anderson (1995), as well as many models proceed by immediate nitrification of the released ammonia to nitrate under oxic conditions (Eq. 9), or by immediate oxidation of ammonia to $\mathrm{N}_{2}$ under suboxic conditions (Eq. 17). In this case, the right hand sides of the oxic (Eq. 10) and suboxic (Eq. 18) processes differ both in terms of products as well as in oxidation states of nitrogen. As a consequence the relationships between nitrate vs. oxygen requirement deviate from the classical 4/5 ratio. For example, the relationship between "Complete" Denitrification (CD, i.e., denitrification with immediate oxidation of the ammonia released from organic matter to $\mathrm{N}_{2}$ which, according to Eq. (18), needs $4 / 5 R_{0}+3 / 5 d$ moles 
of nitrate) and aerobic remineralisation with subsequent nitrification (CR which, according to Eq. (10) consumes $R_{0}+2 d$ moles of oxygen) gives:

$R_{\mathrm{HNO}_{3}: \mathrm{O}_{2}}=\frac{4 / 5 R_{0}+3 / 5 d}{R_{0}+2 d}$

For example, Richards (1965) (and Anderson, 1995) evaluate 138 (and 150) moles oxygen demand for complete remineralisation to nitrate under oxic conditions, and $94.4=4 / 5 \times 106+3 / 5 \times 16$ (and 104) moles nitrate demand under suboxic conditions, the ratio thus being $\approx 0.7$ ( 0.68 and 069, respectively; cf. also in Table 2).

Through $R_{0}$ the ratio given by Eq. (23) depends on the amount of "excess" hydrogen $\left(R_{0}=a+1 / 4 z\right.$ : see Eq. 5) and increases with increasing excess hydrogen. Thus, the more hydrogen-rich substances (lipids $>$ polysaccharides $>$ proteins) the organic matter contains, the higher the nitrate demand of denitrification becomes in comparison to oxic remineralisation. In the theoretical limit of $R_{0} \rightarrow \infty$ we obtain $R_{\mathrm{HNO}_{3}: \mathrm{O}_{2}} \rightarrow 4 / 5$. Note also that CR decreases the alkalinity (TA) by $(d+1)$ moles, whereas CD increases TA by $4 / 5, a+1 / 5 b-2 / 5 c$ moles ( -17 and +93.5 , respectively, according to Redfield stoichiometry: cf. Sect. 3.1.3 and Table 1).

\subsubsection{How much fixed $\mathbf{N}$ and nitrate is removed during complete denitrification?}

The above considerations provide some insight into the dependence of fixed $\mathrm{N}$ (as organic matter, ammonia, nitrate or nitrite) removal on the supply of organic matter to the deep ocean: taking the "Complete" Denitrification (CD as of Eq. (18), i.e., assuming the "Richards" approach to anaerobic ammonia oxidation), and relating it to the amount of organic nitrogen denitrified (cf. Table 2), yields the ratio

$R_{N_{2}: N_{\text {org }}}=2 \frac{2 / 5 R_{0}+4 / 5 d}{d}=\frac{4}{5} \frac{R_{0}+2 d}{d}$

That is, per mole organic $\mathrm{N}\left(N_{\text {org }}\right)$ denitrified, $\approx 7$ moles fixed $\mathrm{N}$ are lost from the system (e.g. according to the Redfield ratio with $R_{0}=106$ and $d=16, R_{\mathrm{N}: \mathrm{Norg}}=6.9$; cf also $-2 \mathrm{~N}_{2} / \mathrm{N}_{\text {org }}$ for CD in Table 2). On long time scales, for the global oceanic nitrogen inventory to be in equilibrium, the fixed nitrogen lost via denitrification would have to be supplied again to the system either via nitrogen fixation or atmospheric deposition. Interestingly, such a supply does not automatically lead to an increase in fixed nitrogen: results from a box model study suggest that if the newly fixed $\mathrm{N}$ is transformed into organic matter above suboxic areas and, upon sinking into the suboxic environment, is denitrified, nitrogen fixation may generate an even greater loss of fixed nitrogen in the suboxic areas below (e.g. Canfield, 2006). Note however that these results depend on the location of $\mathrm{N}$ addition relative to the suboxic waters and on the circulation pathways connecting $\mathrm{OMZ}$ and upwelling areas.
In the "Complete" Denitrification, the moles of $\mathrm{N}$ produced in form of $\mathrm{N}_{2}$ (i.e., 2 moles of $\mathrm{N}$ per mole $\mathrm{N}_{2}$ ) versus moles of $\mathrm{HNO}_{3}$ consumption can be calculated from:

$R_{\mathrm{N}_{2}: \mathrm{HNO}_{3}}=1+\frac{d}{4 / 5 R_{0}+3 / 5 d}$

(see also Table 1). Considering the stoichiometric range for the organic matter composition (see Table 1), the $\mathrm{N}_{2}$ production (in moles of $\mathrm{N}$ ) versus $\mathrm{HNO}_{3}$ consumption from $+115 \%$ $(a=106 ; b=175 ; c=42 ; d=16$; Anderson, 1995$)$ to $+145 \%$ ( $a=53 ; b=7 ; c=23 ; d=16$; Laws (1991) for algal proteins). Slightly more $\mathrm{N}_{2}$ is produced than nitrate is consumed. However, it has recently been reported that the excess $\mathrm{N}_{2}$ directly measured in the Arabian Sea (Devol et al., 2006) may exceed the nitrate deficit by more than a factor 2. From Eqs. (24) and (25) we can deduce that more $\mathrm{N}_{2}$ can be produced than $\mathrm{HNO}_{3}$ is consumed. However, for reasonable assumptions about the composition of organic matter the excess $\mathrm{N}_{2}$ production is limited to about $145 \%$. If the considerably higher excess $\mathrm{N}_{2}$ estimated from observations is confirmed, one of the possible explanations (cf. Codispoti et al., 2001) is that denitrification does not follow the stoichiometries reported in Table 1.

In the above comparison of "Complete" Denitrification (CD: denitrification with oxidation of the ammonia) and also of "Complete" aerobic Remineralisation (CR: remineralisation plus nitrification), we assumed that during both aerobic and anaerobic remineralisation ammonia is immediately oxidised to nitrate and dinitrogen, respectively (no accumulation of ammonia; Richards, 1965). In this case, models considering only dissolved inorganic nitrogen would induce the same biogeochemical effect associated with the remineralisation mechanisms as models that explicitly distinguish between nitrate and ammonia. Nevertheless, the coupling and decoupling between different processes or intermediate steps, mainly depends on the speed of the different process rates. Resolving these rate dependencies requires the separate consideration of at least two pools of inorganic nitrogen (ammonia and nitrate).

\section{Parameterisation of stoichiometry in global models}

Using the above considerations about the relation between organic matter stoichiometry and the stoichiometries of the different aerobic and anaerobic processes, we now aim to examine the parameterisation in four different global biogeochemical models: HAMOCC (in the setup presented in Wetzel, 2004; Maier-Reimer et al., 2005), PISCES (after Aumont, 1998; Aumont and Bopp, 2006), BEC (as described in Moore and Doney, 2007) and SCHMITTNER (as in Schmittner et al., 2008).

Note that our investigation refers to specific setups of the different models; the exact parameterisation (e.g. C/P ratio, 
oxygen demand of remineralisation) may differ in later experiments and be subject to change in the future. Therefore, the model structures as described here should not be regarded as static, but mainly as examples for numerical simulation of oceanic biogeochemistry. Our aim is not to criticize some models used in the past, but to point out possible sources of inconsistencies in the implicit assumptions of biogeochemical ocean models in general, and to encourage the use of full and consistent stoichiometric descriptions of organic matter in the models' formulations and descriptions.

\subsection{Process parameterisations}

In the models investigated, aerobic remineralisation is a function of both particulate and dissolved organic matter, except for the SCHMITTNER model, where only particulate organic matter remineralisation is considered. In addition, remineralisation is a function of depth (PISCES) or a function of temperature (BEC, SCHMITTNER). All four models explicitly simulate denitrification, although its parameterisation differs from that of the aerobic remineralisation in their substrate requirements. For example, in HAMOCC's suboxic zones only particulate matter is subject to anaerobic degradation. Anaerobic remineralisation of Dissolved Organic Matter (DOM) may only be required if the remineralisation of DOM in the overlying oxic layers is slow enough to allow the build-up of significant DOM concentrations in the suboxic zones.

For denitrification, the maximum rates are always lower than for aerobic remineralisation, between a factor of 1 (PISCES) and 5 (SCHMITTNER). The oxygen threshold, below which denitrification and nitrate consumption start, is typically set to values between $4 \mu \mathrm{M}$ (e.g. BEC) and $5 \mu \mathrm{M}$ (e.g. SCHMITTNER). The different formulations of the remineralisation and denitrification rates as a function of ambient oxygen levels are illustrated in Fig. 1. The $\mathrm{O}_{2}$ threshold implicitly separates the rate corresponding to aerobic remineralisation (CR) and to denitrification (CD). For HAMOCC, the illustration of the slope (here between 4 and $6 \mu \mathrm{M}$ ) corresponds to a case with sufficiently detritus (DET) and Dissolved Organic Matter (DOM) for CR, and DET and nitrate for $\mathrm{CD}$ (no limitation of the remineralisation by the organic matter). For PISCES, the total aerobic and anaerobic remineralisation does not depend on $\mathrm{O}_{2}$, but below $6 \mu \mathrm{M}$ a fraction is remineralised by denitrification, increasing when $\mathrm{O}_{2}$ becomes lower $\left(100 \%\right.$ for $\left.\mathrm{O}_{2}=0 \mu \mathrm{M}\right)$. The $\mathrm{CR}$ and $\mathrm{CD}$ rates vary with depth and DOM, and also depend on the bacterial activity, parameterised as a function of zooplankton. For $\mathrm{BEC}$, the $\mathrm{CR}$ and $\mathrm{CD}$ rates depend on temperature, and on nitrate, turning off $\mathrm{CD}$ when nitrate concentration is higher than $32 \mu \mathrm{M}$. For the SCHMITTNER model, the CR and CD rates depend on temperature. The threshold in $\mathrm{O}_{2}$ for the onset of denitrification is $5 \mu \mathrm{M}$, but it is a "smooth" transition mediated by the tanh function.

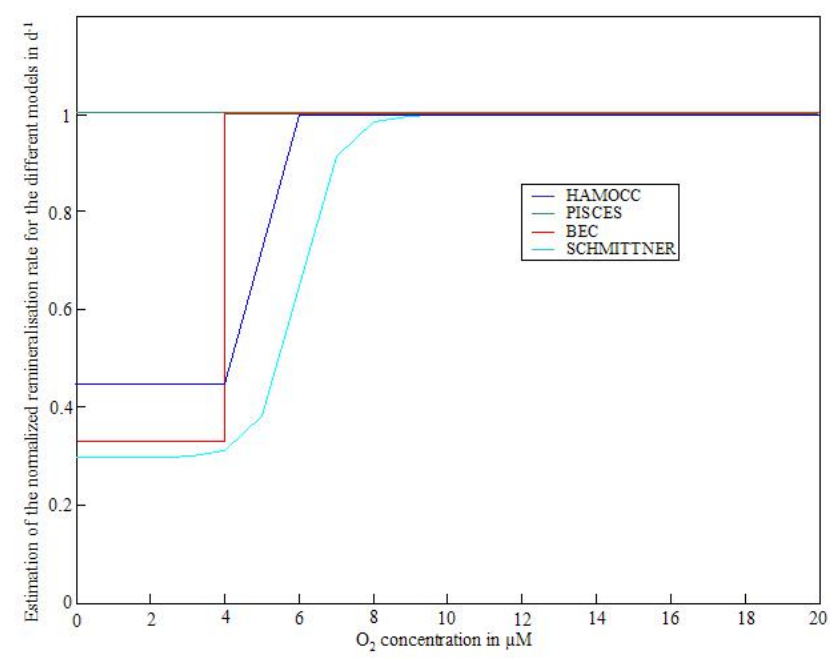

Fig. 1. Plot of the remineralisation, normalised to 1 at high oxygen levels, rate versus $\mathrm{O}_{2}$ concentration, illustrating the different formulations used in HAMOCC, PISCES, BEC and SCHMITTNER BGC models.

Among the models considered, $\mathrm{N}_{2}$ production is modeled explicitly only in the HAMOCC model. $\mathrm{N}_{2} \mathrm{O}$ production is also considered in HAMOCC as well as in unpublished versions of PISCES and the SCHMITTNER model. None of the models considered here includes anammox. With the exception of HAMOCC, they do not include sedimentary denitrification, which would provide a large and possibly less climate-sensitive (long timescale) sink for fixed nitrogen. Nitrification is taken into account explicitly in PISCES and BEC, and implicitly in HAMOCC and SCHMITTNER, as these two latter models consider only dissolved inorganic nitrogen (usually interpreted as nitrate) but not ammonium.

Nitrogen fixation, being the counterpart (on long enough time scales) to the removal of fixed $\mathrm{N}$ via denitrification, is considered in all models at different levels of complexity, from a simple relaxation towards fixed stoichiometric ratios of nitrate and phosphate, to explicit consideration of diazotroph physiology.

\subsection{Parameterisation of $\mathrm{OM}$ stoichiometry and rem- ineralisation}

The four BGC models considered in this study all use the same N/P ratio of 16 , but differ with respect to the C/P ratio (see Table 2). Whereas $\mathrm{C} / \mathrm{P}$ are similar $(\approx 120)$ in the HAMOCC, PISCES and BEC models, the OM contains less carbon $(\mathrm{C} / \mathrm{P}=112)$ in the SCHMITTNER model. Apparently, the SCHMITTNER model considers an OM with less carbon (e.g. carbohydrates) and therefore relatively more nitrogeneous reduced matter (e.g. proteins), as also considered by Redfield et al. (1963) and Anderson (1995). 
Table 2. Stoichiometry in main BGC models for organic matter with 1 mole of phosphorus: HAMOCC, PISCES, BEC and SCHMITTNER, with organic matter $\left(\mathrm{C}_{a} \mathrm{H}_{b} \mathrm{O}_{c} \mathrm{~N}_{d} \mathrm{P}\right)$, complete aerobic remineralisation (CR: cf. Eq. 10) and complete denitrification (CD: cf. Eq. 18) as considered in Table 1. Stoichiometry from Redfield et al. (1963) and Richards (1965), and from Anderson (1995) are called RR and AN, respectively. For the SCHMITTNER model, values in brackets refer to the set-up used by Oschlies et al. (2008).

\begin{tabular}{|c|c|c|c|c|c|c|}
\hline & HAMOCC & PISCES & BEC & SCHMITTNER & RR & AN \\
\hline \multicolumn{7}{|c|}{ Organic matter ratios } \\
\hline $\mathrm{CP}(a)$ & 122 & 122 & 117 & $112(112)$ & 106 & 106 \\
\hline $\mathrm{NP}(d)$ & 16 & 16 & 16 & $16(16)$ & 16 & 16 \\
\hline $\mathrm{H}$ excess $\left(z^{\mathrm{CR}}\right)$, aerobic $^{1}$ & 72 & 72 & 84 & $256(102.4)$ & 0 & 48 \\
\hline $\mathrm{H}$ excess $\left(z^{\mathrm{CD}}\right)$, anaerobic $^{2}$ & -43 & 64 & 84 & $256(102.4)$ & 0 & 48 \\
\hline \multicolumn{7}{|c|}{ Process ratios } \\
\hline$-\mathrm{O}_{2} / \mathrm{P}$ for $\mathrm{CR}$ & 172 & 172 & $170^{3}$ & $208^{4}(169.6)$ & 138 & 150 \\
\hline $\mathrm{HNO}_{3} / \mathrm{P}$ for $\mathrm{CR}^{5}$ & 16 & 16 & 16 & $16(16)$ & 16 & 16 \\
\hline$-\mathrm{HNO}_{3} / \mathrm{P}$ for $\mathrm{CD}$ & $99^{6}$ & $98^{7}$ & 120 & $150.4(119.68)^{8}$ & $94.4^{8}$ & $104^{8}$ \\
\hline$\left(-\mathrm{HNO}_{3} / \mathrm{P}\right)$ for $\mathrm{CD}$, theor ${ }^{9}$ & 122 & 122 & 120 & $150.4(119.68)$ & & \\
\hline $\mathrm{N}_{2} / \mathrm{P}$ for $\mathrm{CD}$ & $57^{6}$ & $68^{8}$ & 68 & $83.2(67.8)^{8}$ & $55.2^{8}$ & $60^{8}$ \\
\hline$-2 \mathrm{~N}_{2} / \mathrm{N}_{\text {org }}$ for $\mathrm{CD}^{10}$ & 7.1 & 8.5 & 8.5 & $10.4(8.5)$ & 6.9 & 7.5 \\
\hline Excess of $\mathrm{N}_{2} /-\mathrm{HNO}_{3}{ }^{11}$ & $+15 \%$ & $+39 \%$ & $+13 \%$ & $+11 \%(+13 \%)$ & $+17 \%$ & $+15 \%$ \\
\hline$-\mathrm{HNO}_{3} /-\mathrm{O}_{2}{ }^{12}$ & 0.58 & 0.57 & 0.71 & $0.72(0.71)$ & 0.68 & 0.69 \\
\hline
\end{tabular}

${ }^{1}$ Calculated from Eq. (27); ${ }^{2}$ Calculated from Eq. (29); ${ }^{3}$ From OM stoichiometry according to Anderson and Sarmiento (1994); ${ }^{4}$ From $\mathrm{O} / \mathrm{N}=13$ and $\mathrm{N} / \mathrm{P}=16 ;{ }^{5}$ From line $c=\mathrm{N} / \mathrm{P} ;{ }^{6}$ From $172 * 2 / 3-16$ for nitrate consumption, and $172 * 1 / 3$ for $\mathrm{N}_{2}$ production; subject to change, E. Maier-Reimer, personal communication, 2008; ${ }^{7}$ Deduced from N/C ratio of 0.8 for denitrification multiplied by $a=\mathrm{C} / \mathrm{P} ;{ }^{8} \mathrm{Calculated}$ from Eq. (18) or Table 1; ${ }^{9}$ Calculated from Eq. (28), using the model's prescribed $\mathrm{O}_{2}$ demand, C/P and N/P.; ${ }^{10}$ From $\mathrm{N}_{2} /(\mathrm{P} \times d)$; for RR and $\mathrm{AN}$ this corresponds to Eq. (24); ${ }^{11}$ From $\left(2 \mathrm{~N}_{2} / \mathrm{P}\right) /\left(\mathrm{HNO}_{3} / \mathrm{P}\right)-1$; for RR and AN this corresponds to Eq. (25); $\left.{ }^{12} \mathrm{From}_{(\mathrm{HNO}} / \mathrm{P}\right) /\left(\mathrm{O}_{2} / \mathrm{P}\right)$; for RR and AN this corresponds to Eq. (23).

Whereas the $-\mathrm{O}_{2} / \mathrm{P}$ ratio for aerobic remineralisation is similar $(\approx 170)$ for HAMOCC, PISCES and BEC, the SCHMITTNER model assumes that about $20 \%$ more $\mathrm{O}_{2}$ is consumed during aerobic remineralisation of organic matter. The same tendency can be observed on the $-\mathrm{O}_{2} / \mathrm{C}$ aerobic remineralisation ratio similar $(\approx 1.4-1.5)$ for HAMOCC, PISCES and BEC, whereas the SCHMITTNER model assumes about $25-30 \%$ more $\mathrm{O}_{2}$ is consumed during aerobic remineralisation of organic matter. Further, the nitrate requirement for denitrification varies widely among the models, from 98 (PISCES) to 150.4 (SCHMITTNER) per organic matter with one mole of phosphorus.

Comparing aerobic remineralisation and denitrification, model descriptions often state the ratio of nitrate consumption during denitrification to oxygen consumption during aerobic remineralisation. In the case of the SCHMITTNER model, this is 0.72 , for HAMOCC it is 0.6, whereas BEC uses a ratio of 0.7 similar to that of Redfield et al. (1963) and Anderson (1995).

\subsection{Implicit assumptions on OM stoichiometry imposed by aerobic remineralisation}

In numerical biogeochemical models, the $\mathrm{C} / \mathrm{P}$ (our $a$ ) and $\mathrm{N} / \mathrm{P}$ (our $d$ ) ratios of organic matter are generally prescribed as explicit input parameters. In contrast, the $\mathrm{H}$ excess (determining $\mathrm{H} / \mathrm{P}$ and $\mathrm{O} / \mathrm{P}$ ratios modulo $\mathrm{H}_{2} \mathrm{O}$ ) is often determined implicitly through the choice of the $-\mathrm{O}_{2} / \mathrm{P}$ ratio for the aerobic remineralisation (and, as we will see below, the choice of $-\mathrm{HNO}_{3} / \mathrm{P}$ for denitrification).

To evaluate the implicit assumptions about organic matter composition from the assigned stoichiometric ratios of aerobic remineralisation (usually $a, d$ and oxygen demand), we here refer to the "excess" hydrogen, (i.e., the hydrogen atoms that cannot be combined in a ratio of 2 with oxygen; $z$ of Eq. 2). Equation (3) shows that the oxygen demand for aerobic remineralisation depends on the carbon content ( $x=a$, see Eq. 5) and on $z$ via $R_{0}=a+1 / 4 z$. The models parameterise "complete aerobic remineralisation", i.e. remineralisation plus nitrification, prescribing a $-\mathrm{O}_{2} / \mathrm{P}$ ratio (in the following $R_{0}^{\mathrm{CR}}$ ). Hence,

$R_{0}^{\mathrm{CR}}=R_{0}+2 d=a+2 d+1 / 4 z$ 
(see Table 1), we can express the excess hydrogen that provides the substrate for oxic remineralisation in terms of the models' prescribed oxygen demand for complete remineralisation, $R_{0}^{\mathrm{CR}}$, their $\mathrm{C} / \mathrm{P}(a)$ and N/P $(d)$ ratio:

$z^{\mathrm{CR}}=4 R_{0}^{\mathrm{CR}}-4 a-8 d$

The value of $z^{\mathrm{CR}}$ thus indicates the implicitly assumed organic matter composition in the models that can be diagnosed from $a=\mathrm{C} / \mathrm{P}$ and $d=\mathrm{N} / \mathrm{P}$ ratios of organic matter in combination with the oxygen demand of aerobic remineralisation. Table 2 reveals that for the models considered here, $z^{\mathrm{CR}}$ varies between 72 and 256 and is always much higher than the value of 48 that we evaluate analogously from the organic matter composition determined by observations and compiled by Anderson (1995).

\subsection{Implicit assumptions on OM stoichiometry imposed by denitrification}

The nitrate demand of complete denitrification, $R_{0}^{\mathrm{CD}}=$ $4 / 5 R_{0}+3 / 5 d$ (Table 1 ) can be expressed in terms of the oxygen demand of complete remineralisation $\left(R_{0}^{\mathrm{CR}}\right.$, see Eq. (26) above):

$R_{0}^{\mathrm{CD}}=4 / 5 R_{0}^{\mathrm{CR}}-d=4 / 5(a+2 d+1 / 4 z)-d$

The models usually prescribe the nitrate demand for denitrification: $R_{0}^{\mathrm{CD}}=-\mathrm{HNO}_{3} / \mathrm{P}$ and assume $\mathrm{N}_{2}$ as end product. Like for aerobic processes, from this value, the $\mathrm{C} / \mathrm{P}$ ratio $a$ and the N/P ratio $d$ we can derive the excess hydrogen of organic matter that served as substrate for complete denitrification as a function of $R_{0}^{\mathrm{CD}}$ :

$z^{\mathrm{CD}}=5 R_{0}^{\mathrm{CD}}-4 a-3 d$

Note, that the SCHMITTNER model does not prescribe $R_{0}^{\mathrm{CD}}$, but instead employs $R_{0}^{\mathrm{CD}}+d=4 / 5 R_{0}^{\mathrm{CR}}$, which yields

$R_{0}^{\mathrm{CD}}+d=4 / 5 R_{0}^{\mathrm{CR}}=\frac{4}{5}\left(a+2 d+\frac{1}{4} z\right)$

and

$z^{\mathrm{CD}}=4 R_{0}^{\mathrm{CR}}-4 a-8 d$

That is, for the SCHMITTNER model, we automatically have $z^{\mathrm{CR}}=z^{\mathrm{CD}}$, which would be required for a consistent stoichiometry - i.e., assuming that organic matter composition is the same everywhere, regardless whether in oxic or suboxic zones. Evaluation of $z^{\mathrm{CD}}$ from $a, d$ and the prescribed nitrate demand for denitrification, $R_{0}^{\mathrm{CD}}$, shows, that among the models considered, only BEC and SCHMITTNER fulfill this requirement. PISCES and HAMOCC implicitly assume that the organic matter supplied to and degraded in the suboxic zones contains less "excess" hydrogen (cf. Table 2).
A too low excess hydrogen content results in a too low nitrate consumption. Taking the OM composition as implicitly defined via $R^{\mathrm{CR}}$ and $d$, from Eq. (28), we can evaluate the theoretical nitrate demand per organic matter with one mole of phosphorus for a stoichiometrically consistent nitrate requirement (Table 2: line 4 in the second block). Comparing this theoretical value to the nitrate requirements prescribed in the models shows, that in the HAMOCC and PISCES models, nitrate consumption by denitrification is too low by 23 and, respectively, 24 moles $\mathrm{HNO}_{3}$ per organic matter with one mole of phosphorus supplied. The remarkable difference in anaerobic $\mathrm{H}$ excess between HAMOCC and PISCES constrained by Eq. (29) is mainly due to a highly different $R_{0}^{\mathrm{CD}}$ very sensitive to the assumptions concerning the determination of $\mathrm{N}_{2} / \mathrm{P}$ for CD: 57 for HAMOCC and 68 for PISCES (see notes 6 and 8 in Table 2, respectively). Thus, differences in the implicit OM composition not only exist between the models, but in some cases also between the different remineralisation pathways considered in a single model, the effect of which has yet to be investigated. Given the large variability (and uncertainty; see above) in the parameterisation of sedimentation and remineralisation rate, however, the effect of these important differences might turn out to have a relatively low impact on simulated tracer fields.

\section{Conclusions}

The specific assumptions made about the elemental composition of organic matter simulated in biogeochemical models have consequences for the simulated fluxes of oxygen, nutrients, and carbon. Assuming organic matter rich in hydrogen ( $\mathrm{H}$ excess), such as lipids or proteins (also rich in nitrogen), implies more consumption of $\mathrm{O}_{2}$ during aerobic remineralisation, and also more consumption of $\mathrm{HNO}_{3}$ and more loss of fixed nitrogen as $\mathrm{N}_{2}$ by denitrification, but less production of $\mathrm{N}_{2}$ per $\mathrm{HNO}_{3}$ consumption.

All models considered in this study implicitly assume an efficient coupling between the aerobic remineralisation and nitrification, without any rate limitation of these processes. In addition, the biogeochemical models do not consider the coupling and/or decoupling between the aerobic (aerobic remineralisation, nitrification) and anaerobic (denitrification, anammox, DNRA) processes, which can affect the stoichiometry of the resulting total remineralisation. Indeed, this coupling and/or decoupling between the aerobic and anaerobic processes is only taken into account by an $\mathrm{O}_{2}$ threshold, which is still not very well defined. None of the models considered take into account the coupling and/or decoupling due to the intermediate compounds such as nitrite. Moreover, the effect of all these mechanisms on alkalinity does not always seem to be included in the models, which is an issue that deserves further attention. 
Even in this simplified picture, biogeochemical models may implicitly assume a composition of organic matter that differs for aerobic remineralisation and anaerobic denitrification, with impacts on simulated biogeochemical tracer distributions. It is not impossible that such differences in the remineralisation stoichiometry exist in reality. Models may help to investigate the possible relevance of such differences. In order to do so, however, the explicit and implicit assumptions used by such biogeochemical models must be clearly stated. This note is one attempt to do so.

Acknowledgements. This paper benefitted from discussions with Wolfgang Koeve. We would like to thank Ernst Maier-Reimer, Laurent Bopp, Eric Galbraith and two anonymous reviewers for providing constructive and helpful comments on the models' stoichiometries. The Deutsche Forschungsgemeinschaft (DFG) provided funding through Sonderforschungsbereich 754: "Climate - Biogeochemistry Interactions in the Tropical Ocean".

The service charges for this open access publication have been covered by the Max Planck Society.

Edited by: F. Joos

\section{References}

Altabet, M. A., Francois, R., Murray, D. W., and Prell, W. L.: Climate-related variations in denitrification in the Arabian Sea from sediment ${ }^{15} \mathrm{~N} /{ }^{14} \mathrm{~N}$ ratios, Nature, 373, 506-509, 1995.

Anderson, L.: On the hydrogen and oxygen content of marine phytoplankton, Deep-Sea Res. I, 42, 1675-1680, 1995.

Anderson, L. and Sarmiento, J.: Redfield ratios of remineralization determined by nutrient data analysis, Global Biogeochem. Cy., 8, 65-80, 1994.

Aumont, O.: Etude du cycle naturel du carbone dans un modele 3D de l'ocean mondial, Doctoral Thesis, Paris VI, 346 pp., 1998.

Aumont, O. and Bopp, L.: Globalizing results from ocean in situ iron fertilization studies, Global Biogeochem. Cy., 20, GB2017, doi:10.1029/2005GB002591, 2006.

Boulahdid, M. and Minster, J.-F.: Oxygen consumption and nutrient regeneration ratios along isopycnal horizons in the Pacific Ocean, Mar. Chem., 26, 133-153, 1989.

Brewer, P. and Goldman, J.: Alkalinity changes generated by phytoplankton growth, Limnol. Oceanogr., 21, 108-117, 1976.

Canfield, D.: Models of oxic respiration, denitrification and sulfate reduction in zones of coastal upwelling, Geochim. Cosmochim. Ac., 70, 5753-5765, 2006.

Codispoti, L., Brandes, J., Christensen, J., Devol, A., Naqvi, S., Paerl, H., and Yoshinari, T.: The oceanic fixed nitrogen and nitrous oxide budgets: moving targets as we enter the anthropocene?, Sci. Mar., 65, 85-105, 2001.

Copin-Montegut, C. and Copin-Montegut, G.: Stoichiometry of carbon, nitrogen, and phosphorous in marine particulate matter, Deep-Sea Res. I, 30, 31-46, 1983.

Ganeshram, R. S., Pedersen, T. F., Calvert, S. E., and François, R.: Reduced nitrogen fixation in the glacial ocean inferred from changes in marine nitrogen and phosphorus inventories, Nature, $415,156-159,2002$.
Devol, A., Uhlenhopp, A., Naqvi, S., Brandes, J., Jayakumar, A., Naik, H., Gaurin, S., Codispoti, L., and Yoshinari, T.: Denitrification rates and excess nitrogen gas concentrations in the Arabian Sea oxygen deficient zone, Deep-Sea Res. I, 53, 1533-1547, 2006.

Fraga, F., Rios, A., Perez, F., and Figueras, F.: Theoretical limits of oxygen:carbon and oxygen:nitrogen ratios during photosynthesis and mineralisation of organic matter in the sea, Mar. Chem., 62, 161-168, 1998.

Fraga, F. and Alvarez-Salgado, X.: On the variation of alkalinity during phytoplankton photosynthesis, Cienc. Mar., 31, 627-639, 2005.

Goldman, J. and Brewer, P.: Effect of nitrogen source and growth rate on phytoplankton-mediated changes in alkalinity, Limnol. Oceanogr., 25, 352-357, 1980.

Hedges, J. I., Baldock, J. A., Gélinas, Y., Peterson, M. L., and Wakeham, S. G.: The biochemical and elemental compositions of marine plankton/a NMR perspective, Mar. Chem., 47, 47-63, 2002.

Koeve, W.: Spring bloom carbon to nitrogen ratio of net community production in the temperate N. Atlantic, Deep-Sea Res., 51, 1579-1600, 2004.

Lam, P., Lavik, G., Jensen, M. M., van de Vossenber, J., Schmidt, M., Woebken, D., Gutierrez, D., Amann, R., Jetten, M. S. M, and Kuypers, M. M.: Revising the nitrogen cycle in the Peruvian oxygen minimum zone, P. Natl. Acad. Sci., 106, 4752-4757, 2009.

Laws, E. A.: Photosynthetic quotients, new production and net community production in the open ocean, Deep-Sea Res., 38, 143-167, 1991.

Maier-Reimer, E.: Geochemical cycles in an ocean general circulation model - Preindustrial tracer distributions, Global Biogeochem. Cy., 7, 645-677, 1993.

Maier-Reimer, E., Kriest, I., Segschneider, J., and Wetzel, P.: The HAMburg Ocean Carbon Cycle Model HAMOCC 5.1 - Technical Description Release 1.1, Reports on Earth System Science 14, Max-Planck-Institute for Meteorology, Hamburg, online available at http://www.mpimet.mpg.de/fileadmin/ publikationen/erdsystem_14.pdf, 2005.

Meissner, K. J., Galbraith, E. D., and Völker, C.: Denitrification under glacial and interglacial conditions: A physical approach, Paleoceanography, 20, PA3001, doi:10.1029/2004PA001083, 2005.

Moore, J., Doney, S., Kleypas, J., Glover, D., and Fung, I.: An intermediate complexity marine ecosystem model for the global domain, Deep-Sea Res. II, 49, 403-462, 2002.

Moore, J., Doney, S., and Lindsay, K.: Upper ocean ecosystem dynamics and iron cycling in a global three-dimensional model, Global Biogeochem. Cy., 18, GB4028, doi:10.1029/ 2004GB002220, 2004.

Moore, J. and Doney, S.: Iron availability limits the ocean nitrogen inventory stabilizing feedbacks between marine denitrification and nitrogen fixationg, Global Biogeochem. Cy., 21, GB2001, doi:10.1029/2006GB002762, 2007.

Oschlies, A., Schulz, K. G., Riebesell, U., and Schmittner, A.: Simulated 21 st century's increase in oceanic suboxia by $\mathrm{CO}_{2}-$ enhanced biological carbon export, Global Biogeochem. Cy., 22, GB4008, doi:10.1029/2007GB003147, 2008.

Paulmier, A. and Ruiz-Pino, D.: Oxygen minimum zones (OMZs) in the modern ocean, Prog. Oceanogr., 80(3-4), 113-128, doi: 
10.1029/j.pocean.2008.08.001, 2008

Redfield, A.: On the proportions of organic derivatives in sea water and their relation to the composition of plamkton, in: James Johnstone Memorial Volume, Liverpool, 176-192, 1934.

Redfield, A. C, Ketchum, B. H., and Richards, F. A.: The influence of organisms on the composition of sea-water, in: The Sea, edited by: Hill, M., vol. 2, chap. 2, Interscience, New York, USA, 2677, 1963.

Richards, F.: Anoxic basins and fjords, in: Chemical Oceanography, edited by: Riley, J. and Skirrow, G., vol. 1, chap. 13, Academic Press, New York, USA, 611-645, 1965.

Sambrotto, R. N., Savidge, G., Robinson, C., Boyd, P., Takahashi, T., Karl, D. M., Langdon, C., Chipman, D., Marra, J., and Codispoti, L.: Elevated consumption of carbon relative to nitrogen in the surface ocean, Nature, 363, 248-250, 1993.

Schartau, M. and Oschlies, A.: Simulataneous data-based optimization of a 1D-ecosystem model at three locations in the North Atlantic: Part I - Method and parameter estimates, J. Mar. Res., 61, 765-793, 2003.

Schmittner, A., Oschlies, A., Matthews, H., and Galbraith, E.: Future changes in climate, ocean circulation, ecosystems, and biogeochemical cycling simulated for a business-as-usual $\mathrm{CO}_{2}$ emission scenario until year $4000 \mathrm{AD}$, Global Biogeochem. Cy., 22, GB1013, doi:10.1029/2007GB002953, 2008.

Schneider, B., Schlitzer, R., Fischer, G., and Nötig, E.-M.: Depthdependent elemental composition of particulate organic matter (POM) in the ocean, Global Biogeochem. Cy., 17(2), 1032, doi:10.1029/2002GB001871, 2003.

Six, K. D. and Maier-Reimer, E.: Effects of plankton dynamics on seasonal carbon fluxes in an ocean general circulation model, Global Biogeochem. Cy., 10, 559-583, 1996.
Stramma, L., G. C. Johnson, J. Sprintall, and V. Mohrholz: Expanding oxygen-minimum zones in the tropical oceans, Science, 320, 655-658, 2008.

Suntharalingam, P., Sarmiento, J., and Toggweiler, J.: Global significance of nitrous-oxide production and transport from oceanic low-oxygen zones - A modeling study, Global Biogeochem. Cy., 14, 1353-1370, 2000.

Takahashi, T., Broecker, W., and Langer, S.: Redfield ratio based on chemical data from isopycnal surfaces, J. Geophys. Res., 90, 6907-6924, 1985.

Van Mooy, B., Keil, R., and Devol, A.: Impact of suboxia on sinking particulate organic carbon: Enhanced carbon flux and preferential degradation of amino acids via denitrificiation, Geochim. Cosmochim. Ac., 66, 457-465, 2002.

Weaver, A. J., Eby, M., Wiebe, E. C., Bitz, C. M., Duffy, P. B., Ewen, T. L., Fanning, A. F., Holland, M. M., MacFadyen, A., Matthews, H. D., Meissner, K. J., Saenko, O., Schmittner, A., Wang, H., and Yoshimori, M.: The UVic earth system climate model: Model description, climatology, and applications to past, present and future climates, Atmos.-Ocean, 39, 361-428, 2001.

Wetzel, P.: Interannual and Decadal Variability in the Air-Sea Exchange of $\mathrm{CO}_{2}$ - a Model Study, Reports on Earth System Science 7, Max-Planck-Institute for Meteorology, Hamburg, online availabel at: http://www.mpimet.mpg.de/fileadmin/ publikationen/erdsystem_7.pdf, 2004.

Wolf-Gladrow, D., Zeebe, R., Klaas, C., Körtzinger, A., and Dickson, A.: Total alkalinity: The explicit conservative expression and its application to biogeochemical processes, Mar. Chem., 106, 287-300, 2007. 